\title{
Milk fatty acid profile and dairy sheep performance in response to diet supplementation with sunflower oil plus incremental levels of marine algae
}

\author{
P. G. Toral, ${ }^{*}$ G. Hervás, ${ }^{*}$ P. Gómez-Cortés, † P. Frutos, ${ }^{, 1}$ M. Juárez,† and M. A. de la Fuente $†$ \\ *Instituto de Ganadería de Montaña (CSIC-ULE), Finca Marzanas s/n. 24346 Grulleros, León, Spain \\ †Instituto del Frío (CSIC), José Antonio Novais 10, 28040 Madrid, Spain
}

\begin{abstract}
In an attempt to develop strategies for enhancing the nutritional value of sheep milk fat, dairy ewe diet was supplemented with 3 incremental levels of marine algae (MA), in combination with sunflower oil, to evaluate the effects of these marine lipids on milk fatty acid (FA) profile and animal performance. Fifty Assaf ewes in mid lactation were distributed in 10 lots of 5 animals each and allocated to 5 treatments (2 lots per treatment): no lipid supplementation (control) or supplementation with $25 \mathrm{~g}$ of sunflower oil $/ \mathrm{kg}$ of DM plus 0 $(\mathrm{SO}), 8\left(\mathrm{SOMA}_{1}\right), 16\left(\mathrm{SOMA}_{2}\right)$, or $24\left(\mathrm{SOMA}_{3}\right) \mathrm{g}$ of MA $(56.7 \%$ ether extract) $/ \mathrm{kg}$ of DM. Milk production and composition, including FA profile, were analyzed on d $0,3,7,14,21$, and 28 of treatment. Neither intake nor milk yield were significantly affected by lipid addition, but all MA supplements decreased milk fat content from d 14 onward, reaching a $30 \%$ reduction after $28 \mathrm{~d}$ on $\mathrm{SOMA}_{3}$. This milk fat depression might be related not only to the joint action of some putative fat synthesis inhibitors, such as trans-9,cis-11 C18:2 and probably trans-10 C18:1, but also to the limited ability of the mammary gland to maintain a desirable milk fat fluidity, that would have been caused by the noticeable increase in trans-C18:1 together with the lowered availability of stearic acid for oleic acid synthesis through $\Delta^{9}$-desaturase. Furthermore, all lipid supplements, and mainly MA, reduced the secretion of de novo FA (C6:0-C14:0) without increasing the yield of preformed FA (>C16). Supplementation with sunflower oil plus MA resulted in larger increases in cis-9,trans-11 C18:2 than those observed with sunflower oil alone, achieving a mean content as high as $3.22 \%$ of total FA and representing a more than 7 -fold increase compared with the control. Vaccenic acid (trans-11 C18:1) was also significantly enhanced (on average $+794 \%$ in SOMA treatments), as was C22:6 n-3 (DHA) content, although
\end{abstract}

Received September 25, 2009

Accepted December 15, 2009

${ }^{1}$ Corresponding author: p.frutos@eae.csic.es the transfer efficiency of the latter, from the diets to the milk, was very low (5\%). However, the highest levels of MA inclusion $\left(\mathrm{SOMA}_{2}\right.$ and $\mathrm{SOMA}_{3}$ ) reduced the milk n-6:n-3 ratio, but MA supplements caused an important increase in trans-10 C18:1, which would rule out the possibility that this milk has a healthier fat profile before determining the specific role of each individual FA and ensuring that this trans-FA is at least innocuous in relation to cardiovascular disease risk.

Key words: conjugated linoleic acid, milk fat depression, n-3, trans fatty acid

\section{INTRODUCTION}

A growing epidemic of chronic disease related to dietary and lifestyle changes afflicts both developed and developing countries, with cardiovascular disease, cancer, and diabetes nowadays being among the most important causes of premature death (WHO, 2003). The discovery of potential anticarcinogenic, antiatherosclerotic, and antidiabetic effects of conjugated linoleic acid (CLA; Pariza et al., 2001; Shingfield et al., 2008) and the recognized role in human health of the n-3 fatty acids (FA; Simopoulos, 2008) have led to an increasing number of studies over the past decade seeking to enhance the content of these bioactive compounds in ruminant-derived products, mainly in cow milk. Even though consumption of ovine milk might have several nutritional advantages over bovine milk consumption, such as its higher mineral (e. g., Ca, P, and $\mathrm{Mg}$ ), and caprylic (C8:0) and capric (C10:0) acid contents and its easier digestibility (Recio et al., 2009), research in ewes is still scarce.

In a previous study in dairy sheep, inclusion in the diet of sunflower oil (SO), rich in linoleic acid, induced a 4-fold increase in milk CLA content (Hervás et al., 2008), presumably through increased ruminal formation of vaccenic acid (VA; trans-11 C18:1; Palmquist et al., 2005; Chilliard et al., 2007), which serves as a substrate for endogenous synthesis of the major isomer of CLA, rumenic acid (RA; cis-9,trans-11 CLA) not only in the ruminant mammary gland but also in some human tissues (Palmquist et al., 2005). The use of SO 
in combination with long-chain n-3 polyunsaturated fatty acids (PUFA) of marine lipids, which are inhibitors of the ruminal reduction of trans-C18:1 to stearic acid (C18:0; Loor et al., 2005; Or-Rashid et al., 2008), would induce further increases in VA ruminal out-flow and subsequently RA mammary synthesis, as reported in cows (Shingfield et al., 2006; Cruz-Hernández et al., 2007). However, the nutritional strategy of supplying a source of linoleic acid together with marine lipids may also increase some trans-C18:1 in ruminant milk fat (Reynolds et al., 2006; Shingfield et al., 2006; CruzHernández et al., 2007), whose potential specific role for human health is still unclear (Shingfield et al., 2008).

In addition to the effects addressed to modify milk FA profile, the inclusion of fish oil in the diet appears to affect animal performance, reducing milk fat content in both dairy ewes (Capper et al., 2007) and cows (Griinari and Bauman, 2006; Cruz-Hernández et al., 2007; Gama et al., 2008). Addition of marine algae (MA), on the contrary, has been reported to induce milk fat depression (MFD) in cows (Franklin et al., 1999; Offer et al., 2001; Boeckaert et al., 2008) but not in sheep (Papadopoulos et al., 2002; Reynolds et al., 2006) and is responsible for a greater transfer efficiency of longchain n-3 PUFA into the milk in this species than in cattle (Papadopoulos et al., 2002; Reynolds et al., 2006; Chilliard et al., 2007). Notwithstanding, effects of MA inclusion described in the literature are quite inconsistent and might depend on several factors, such as basal diet composition and algae dosage (Reynolds et al., 2006). This fact, together with the scarcity of published studies on this issue, makes it difficult to establish an appropriate level of MA inclusion in the diet of sheep to obtain a healthier milk FA profile for human consumers, with no detrimental effects on animal performance. The objective of this study was therefore to investigate the effect of the dietary inclusion of incremental levels of MA, in combination with SO, on dairy ewes' performance and milk FA profile.

\section{MATERIALS AND METHODS}

\section{Animals, Experimental Diets, and Management}

Fifty multiparous Assaf ewes $(\mathrm{BW}=84.9 \mathrm{~kg}$; $\mathrm{SD}=$ 11.75) in mid lactation (at wk 14 at the beginning of the experiment; $\mathrm{SD}=1.0$ ) were stratified according to milk production, BW, days postpartum, and number of lactation, randomly distributed in 10 lots of 5 animals each, and allocated to 5 experimental treatments (2 lots per treatment): no lipid supplementation or supplementation with SO (Carrefour S.A., Spain), either alone or in combination with 3 increasing levels of MA (DHA Gold Animal Feed Ingredient, Martek
Biosciences Corp., Columbia, MD; $567 \mathrm{~g}$ of ether extract/kg of DM).

The diets, prepared weekly, consisted of a TMR based on alfalfa hay (particle size $>4 \mathrm{~cm}$ ) and a concentrate (50:50) either without lipid supplementation (control diet; negative control) or supplemented with $25 \mathrm{~g}$ of $\mathrm{SO} / \mathrm{kg}$ of DM plus 0 (SO diet; positive control), $8\left(\mathbf{S O M A}_{1}\right), 16\left(\mathbf{S O M A}_{\mathbf{2}}\right)$, or $24\left(\mathbf{S O M A}_{\mathbf{3}}\right) \mathrm{g}$ of MA/ $\mathrm{kg}$ of DM. The ingredients and chemical composition of the 5 experimental diets, which included molasses to avoid selection of dietary components, are given in Table 1. During a 3-wk adaptation period (before commencing the trial), all animals received the control diet. Clean water and a vitamin-mineral supplement were always available and fresh diets were offered daily ad libitum at 0900 and $1900 \mathrm{~h}$.

The ewes were milked at approximately 0830 and $1830 \mathrm{~h}$ in a $1 \times 10$ stall milking parlor (DeLaval, Madrid, Spain). The experiment lasted for 4 wk and was carried out in accordance with Spanish Royal Decree $1201 / 2005$ for the protection of animals used for experimental purposes.

\section{Measurements, Sample Collection, and Chemical Analyses}

Samples of offered and refused diets were collected once a week, stored at $-30^{\circ} \mathrm{C}$, and then freeze-dried. The DMI was recorded weekly for each experimental lot. Diet samples were analyzed for DM (ISO, 1999a), ash (ISO, 2002a), and CP (ISO, 2005). Neutral detergent fiber and ADF were determined as described by Ankom Technology (Ankom, 2006a,b). Neutral detergent fiber was assayed with sodium sulfite and $\alpha$-amylase and expressed with residual ash (the latter also for ADF). The content of ether extract in the diets was determined by the Ankom Filter Bag Technology (American Oil Chemists' Society Official Procedure Am 5-04; AOCS, 2008).

Individual milk yield was recorded on d $0,3,7,14$, 21 , and 28, both at morning and evening milkings. With the same frequency, milk samples for the analysis of fat, protein, and TS were collected from each animal, composited according to morning and evening milk yield, and treated with natamycin. The protein, fat, and TS concentrations were determined by infrared spectrophotometry (ISO, 1999b) using a MilkoScan 255 A/S N (Foss Electric, Hillerød, Denmark).

Milk FA composition was determined in untreated samples from each experimental lot and composited according to individual milk production within day. Milk fat was extracted as described by Luna et al. (2005), and FA methyl esters (FAME) were prepared by basecatalyzed methanolysis of the glycerides (ISO, 2002b). 
Table 1. Ingredients and chemical composition of the experimental $\operatorname{diets}^{1}$

\begin{tabular}{|c|c|c|c|c|c|}
\hline Item & Control & $\mathrm{SO}$ & $\mathrm{SOMA}_{1}$ & $\mathrm{SOMA}_{2}$ & $\mathrm{SOMA}_{3}$ \\
\hline \multicolumn{6}{|c|}{ Ingredient, $\mathrm{g} / \mathrm{kg}$ of fresh matter } \\
\hline Dehydrated alfalfa hay & 484 & 474 & 470 & 466 & 462 \\
\hline Whole corn grain & 136 & 133 & 131 & 130 & 129 \\
\hline Whole barley grain & 175 & 170 & 169 & 168 & 167 \\
\hline Soybean meal & 97 & 95 & 94 & 93 & 92 \\
\hline Beet pulp & 49 & 47 & 47 & 47 & 46 \\
\hline Molasses & 37 & 36 & 36 & 36 & 36 \\
\hline Feed supplement ${ }^{2}$ & 22 & 21 & 21 & 21 & 21 \\
\hline Sunflower oil ${ }^{3}$ & 0 & 24 & 24 & 24 & 24 \\
\hline Marine algae $^{4}$ & 0 & 0 & 8 & 15 & 23 \\
\hline \multicolumn{6}{|c|}{ Chemical composition, $\mathrm{g} / \mathrm{kg}$ of DM } \\
\hline $\mathrm{OM}$ & 896 & 900 & 897 & 893 & 899 \\
\hline $\mathrm{CP}$ & 161 & 159 & 158 & 159 & 158 \\
\hline $\mathrm{NDF}$ & 308 & 304 & 296 & 300 & 293 \\
\hline $\mathrm{ADF}$ & 198 & 195 & 190 & 191 & 187 \\
\hline Ether extract & 26 & 50 & 54 & 57 & 63 \\
\hline
\end{tabular}

${ }^{1}$ Diets included a TMR without lipid supplementation (control) or supplementation with $25 \mathrm{~g}$ of sunflower oil/ $\mathrm{kg}$ of DM plus $0(\mathrm{SO}), 8\left(\mathrm{SOMA}_{1}\right), 16\left(\mathrm{SOMA}_{2}\right)$, or $24\left(\mathrm{SOMA}_{3}\right) \mathrm{g}$ of marine algae $(56.7 \%$ ether extract $) / \mathrm{kg}$ of DM.

${ }^{2}$ INA OV1, Evialis, Madrid, Spain. Contained (g/kg): $\mathrm{NaHCO}_{3}(333), \mathrm{CaCO}_{3}(311), \mathrm{Ca}_{2} \mathrm{HPO}_{4}(133)$, mine salt (111), and mineral and vitamins (111).

${ }^{3}$ Contained (\% total fatty acid methyl esters): C16:0 (7.5), C18:0 (4.3), C18:1 (26.3), and C18:2 (60.5).

${ }^{4}$ As declared by the supplier (Martek Biosciences Corp., Columbia, MD), marine algae (DHA Gold Animal Feed Ingredient) contained (g/kg of DM): OM (910), CP (170), crude fiber (46), and ether extract (557). Fatty acid composition (\% FFA): C14:0 (8.5), C16:0 (23.2), C20:3 n-6 (1.6), C20:5 n-3 (1.9), C22:5 n-6 (17.7), and C22:6 n-3 (42.3).

Analysis of FAME in hexane was performed on a gas chromatograph (Agilent 6890 N Network System, Palo Alto, CA) with auto injector and fitted with a flame ionization detector. The FAME profile was determined by split injection (1:100) onto a CP-Sil 88 fused silica capillary column $(100 \mathrm{~m} \times 0.25 \mathrm{~mm}$ i.d., $0.20 \mu \mathrm{m}$ film thickness; Varian, Middelburg, the Netherlands) using the same programmed temperature gradient method as described in Hervás et al. (2008). Separation of CLA methyl esters was carried out using an HPLC (Shimadzu, model SPE-MA10AVP, Kyoto, Japan) equipped with a diode array detector operated at $233 \mathrm{~nm}$. Three ChromSpher 5 Lipid analytical silver-impregnated columns $(250 \mathrm{~mm} \times 4.6 \mathrm{~mm}$ i.d. stainless steel; $5 \mu \mathrm{m}$ particle size; Varian) were used in series. The mobile phase was $0.1 \%$ acetonitrile and $0.5 \%$ diethyl ether in hexane and was operated isocratically at a flow-rate of $1.0 \mathrm{~mL} / \mathrm{min}$. Quantification of individual FAME was made by reference to a milk fat with a known composition (CRM 164; European Community Bureau of Reference, Brussels, Belgium). Individual CLA isomers were identified by comparison with standard mixtures distributed by Nu-Chek Prep Inc. (Elysian, MN). GLC461 from Nu-Chek Prep Inc. was also used to identify other FA.

\section{Calculations and Statistical Analyses}

Milk fat melting point was calculated as described by Jensen and Patton (2000) using FA with a molar fraction $>0.1 \%$ in milk fat ( $97 \%$ of total FA). For each individual FA, melting point was obtained from Gunstone et al. (1994). Transfer efficiency of C22:6 n-3 (docosahexaenoic acid; DHA) from diet to milk was calculated as [(g of milk fat yield $\times \%$ DHA in milk fat $) /$ $(\mathrm{DMI} \times \%$ DHA in the TMR) $] \times 100$. Desaturase index was calculated as product of $\Delta^{9}$-desaturase/(product of $\Delta^{9}$-desaturase + substrate of $\Delta^{9}$-desaturase).

All analyses were performed using the SAS software package (version 9.1, SAS Institute Inc., Cary, NC). Data on DMI, and milk yield and composition, as well as FA composition, were analyzed by repeated measurement analysis using the MIXED procedure of SAS and assuming a covariance structure on the basis of Schwarz's Bayesian information model fit criteria. The statistical model included the fixed effects of diet, time, their interaction, and the initial record measured at d 0 (covariate). For all data collected either individually (milk yield and composition) or per lot (DMI and FA composition), the lot was nested within the diet to contrast the effect of the lipid supplementation. Least squares means (adjusted for the covariance) are reported throughout. They were generated and separated using the PDIFF option of SAS incorporating the Tukey test for pairwise comparison of treatment means, both for main or interactive effects when they were significant. Pearson correlation coefficients (r) were generated for associations between some FA, milk yield, and fat content with the CORR procedure of SAS using the 
TORAL ET AL.

Table 2. DMI, milk yield, and milk composition in ewes fed the experimental diets

\begin{tabular}{|c|c|c|c|c|c|c|c|c|c|}
\hline Item & \multicolumn{5}{|c|}{ Treatment $^{1}$} & $\mathrm{SED}^{2}$ & \multicolumn{3}{|c|}{$P$-value ${ }^{3}$} \\
\hline DMI, g/d & 3,280 & 3,585 & 3,608 & 3,436 & 3,459 & 211.7 & NS & $* *$ & NS \\
\hline Milk & 2,059 & 2,153 & 2,010 & 2,110 & 1,928 & 134.0 & NS & $* * *$ & NS \\
\hline Protein & 107.1 & 110.1 & 98.7 & 103.4 & 95.5 & 5.62 & NS & $* * *$ & NS \\
\hline Fat & $125.9^{\mathrm{ab}}$ & $140.9^{\mathrm{a}}$ & $115.7^{\mathrm{bc}}$ & $118.4^{\mathrm{bc}}$ & $101.7^{\mathrm{c}}$ & 6.80 & $*$ & $* * *$ & $* *$ \\
\hline Fat & $6.15^{\mathrm{ab}}$ & $6.51^{\mathrm{a}}$ & $5.75^{\mathrm{bc}}$ & $5.67^{\mathrm{bc}}$ & $5.29^{\mathrm{c}}$ & 0.212 & $* *$ & $* * *$ & $* * *$ \\
\hline TS & $16.98^{\mathrm{a}}$ & $17.35^{\mathrm{a}}$ & $16.33^{\mathrm{b}}$ & $16.22^{\mathrm{b}}$ & $15.88^{\mathrm{b}}$ & 0.251 & $* *$ & $* * *$ & $* * *$ \\
\hline
\end{tabular}

${ }^{\mathrm{a}-\mathrm{c}}$ Means within a row with different superscripts differ significantly.

${ }^{1}$ Diets included a TMR without lipid supplementation (control) or supplementation with $25 \mathrm{~g}$ of sunflower oil/kg of DM plus 0 (SO), 8 (SOMA 1 ), $16\left(\mathrm{SOMA}_{2}\right)$, or $24\left(\mathrm{SOMA}_{3}\right) \mathrm{g}$ of marine algae $(56.7 \%$ ether extract $) / \mathrm{kg}$ of DM.

${ }^{2} \mathrm{SED}=$ standard error of the difference.

${ }^{3}$ Probability of significant effects of experimental diet $(\mathrm{D})$, time on $\operatorname{diet}(\mathrm{T})$, and their interaction $(\mathrm{D} \times \mathrm{T})$. NS $=$ not significant $(P>0.10)$. $\dagger P<0.10 ;{ }^{*} P<0.05 ;{ }^{* *} P<0.01 ;{ }^{* * *} P<0.001$.

lot as the experimental unit. Differences were declared significant at $P<0.05$, and values of $P<0.10$ were interpreted as tendencies toward significance.

\section{RESULTS}

\section{Ewe Performance and Milk Composition}

Neither DMI nor milk yield was significantly affected by lipid supplementation $(P>0.10$; Table 2$)$, and, although there were no changes in milk protein yield $(P$ $=0.166)$, its content was slightly reduced when feeding MA $(-4.7 \% ; P=0.030)$. Both milk fat content and yield, however, were significantly affected by the inclusion of lipids in the diet. Thus, all MA supplements decreased milk fat content from d 14 onward (Figure 1), reaching a $30 \%$ reduction after $28 \mathrm{~d}$ on the highest level of MA inclusion $\left(\mathrm{SOMA}_{3} ; P<0.001\right)$. Changes in TS content mirrored those reported for milk fat, and all SOMA diets reduced the percentage of milk solids $(P=0.006)$.

\section{Saturated and Monoenoic FA}

As shown in Table 3, percentages $(\mathrm{g} / 100 \mathrm{~g}$ of total FA) of most short- and medium-chain saturates were significantly reduced in supplemented diets, except for C4:0 (slightly increased; $P=0.009$ ) and C14:0 (unmodified, $P=0.149$ ). Feeding SO significantly decreased C16:0 concentration, but only when fed alone or combined with the lowest dose of MA $\left(\mathrm{SOMA}_{1}\right)$. As observed in Figure 2, stearic acid content was increased with the SO $(+35 \%)$, whereas MA induced a decrease $(P<0.001)$. After only $7 \mathrm{~d}$ on SOMA diets, C18:0 aver- age levels were as low as $2.27 \%$ of total $\mathrm{FA}$ in $\mathrm{SOMA}_{1}$ $(-66 \% ; P<0.001)$ and $1.38 \%$ of total $\mathrm{FA}$ in $\mathrm{SOMA}_{2}$ and $\mathrm{SOMA}_{3}(-79 \% ; P<0.001)$. Percentages of most odd- and branched-chain FA also diminished with lipid supplementation $(P<0.05$; Table 3$)$.

There were also important changes in milk content of almost all monounsaturated FA, with significant diet $\times$ time interactions. Oleic acid (cis-9 C18:1) level was significantly increased with the SO diet $(+20 \%)$, whereas inclusion of MA diminished it $(-29 \%$; Figure 2). All lipid supplements resulted in greater trans-C18:1 percentages, mainly trans-10 and trans-11, which were remarkably enhanced in SOMA diets $(P<0.001)$. The content of VA increased by 8.6 times in $\mathrm{SOMA}_{3}$ treatment (averaging $8 \%$ of total FA; Figure 2), with this elevated level being sustained throughout the whole monitoring period. Milk content of trans-10 C18:1 re-

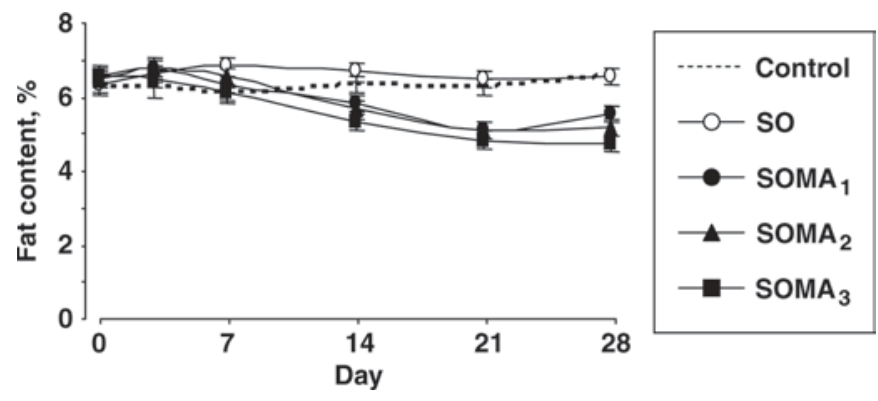

Figure 1. Temporal changes in milk fat content in ewes fed a TMR without lipid supplementation (control) or supplemented with $25 \mathrm{~g}$ of sunflower oil $/ \mathrm{kg}$ of DM plus $0,8,16$, or $24 \mathrm{~g}$ of marine algae $/ \mathrm{kg}$ of $\mathrm{DM}\left(\mathrm{SO}, \mathrm{SOMA}_{1}, \mathrm{SOMA}_{2}\right.$, and $\mathrm{SOMA}_{3}$ diets, respectively). Values are the mean from 2 lots of 5 animals per lot; vertical bars represent the standard error of the means. 
mained statistically unmodified when SO was fed alone, but inclusion of MA induced large increases, especially on d 14 of supplementation $(P<0.001)$.

Finally, the milk fat concentration of other transC18:1 isomers (trans-6+7+8, trans-9, and trans-12) was significantly increased with $\mathrm{SO}$ and $\mathrm{SOMA}_{1}$ treatments (Table 3), except for trans-9, which was also augmented with $\mathrm{SOMA}_{2}$ and $\mathrm{SOMA}_{3}(P<0.001)$.

\section{Conjugated and Nonconjugated Linoleic Acid}

The addition of MA to SO-containing diets resulted in large increases in milk fat RA, much higher than those observed when $\mathrm{SO}$ was supplemented alone $(P$ $<0.001$; Table 3), with the highest concentration corresponding to $\mathrm{SOMA}_{3}$ treatment. As shown in Figure 2, RA content increased sharply during the first $7 \mathrm{~d}$ on SOMA treatments and, after a transient declination, the highest levels were achieved in $\mathrm{SOMA}_{1}$ and $\mathrm{SOMA}_{3}$ on $\mathrm{d} 28(P<0.001)$. Addition of $\mathrm{SO}$ alone induced a constant increase of RA content over the whole period. Trans-7,cis-9 CLA doubled its level with the SO and $\mathrm{SOMA}_{1}$ diets $(P<0.001$; Table 3$)$. A 9-fold increase in trans-9,cis-11 CLA $(P<0.001 ;$ Table 3$)$ was reached after $28 \mathrm{~d}$ on $\mathrm{SOMA}_{2}$ and $\mathrm{SOMA}_{3}$ treatments (Figure 2). Other CLA isomers, such as trans-10,cis-12, were present only in very low concentrations (Table 3; Figure 2).

The most abundant nonconjugated PUFA was linoleic acid (cis-9,cis-12 C18:2), but its level was little modified except for the slight decrease observed with MA $(P=0.006)$. This marine additive significantly augmented the concentration of other, less abundant nonconjugated dienes, such as trans-11, cis-15 C18:2.

\section{Other Polyunsaturated FA}

Lipid inclusion significantly decreased $\alpha$-linolenic acid (C18:3 n-3) in milk fat, whereas C22:6 n-3 (DHA) content showed a sharp increase after the start of MA supplementation $(P<0.001)$, with relatively stable concentration afterward. However, calculated DHA transfer efficiencies from SOMA diets to milk were very low (0.040-0.058). Increases in other long-chain n-3 PUFA, such as C22:5 (docosapentaenoic acid) or C20:5 (eicosapentaenoic acid), were observed only with the medium and high levels of MA inclusion $(P<0.001)$ and, in any event, their content was always below $0.2 \%$ of total FAME. Changes in milk content of n-6 PUFA were of lower magnitude with the exception of the higher levels of C22:5 n-6 obtained with SOMA diets (Table 3).

\section{DISCUSSION}

\section{Ewe Performance and Milk Composition}

Inclusion of free vegetable oils in dairy ewe diet has been reported to have no apparent detrimental effect on DMI and milk yield (Pulina et al., 2006; GómezCortés et al., 2008a; Hervás et al., 2008), and although decreases in feed consumption are frequently observed when feeding marine algae to sheep or cows, this reduction does not always affect milk yield (Franklin et al., 1999; Offer et al. 2001; Papadopoulos et al., 2002).

In relation to milk composition, the $6 \%$ reduction of the TS content found with SOMA treatments was the consequence of the significant decrease in milk protein and fat contents caused by the inclusion of these lipids in the diet. Reductions in milk protein are frequently observed when the diet of dairy ewes is supplemented with oil (Pulina et al., 2006; Gómez-Cortés et al., 2008b) and are generally attributed to reduced AA availability. Previous studies have shown no evidence of MFD in dairy ewes fed free vegetable oils (Pulina et al., 2006; Gómez-Cortés et al., 2008a,b; Hervás et al., 2008), but few experiments have examined the effect of unprotected marine lipids in this species. Furthermore, the reported effects of the latter on ewe milk fat content are very inconsistent, with reductions, no changes, and even increases (Papadopoulos et al., 2002; Reynolds et al., 2006; Capper et al., 2007), which could be mostly accounted for by differences in basal diet composition and lipid dosage.

\section{Milk Fat Depression and Putative Inhibitors}

In dairy cows, MFD induced by the use of free vegetable oils and high-concentrate diets is characterized by increased milk fat concentration of trans-10, cis-12 CLA, a biohydrogenation (BH) intermediate with antilipogenic effect not only in this ruminant species (Chilliard et al., 2007; Shingfield et al., 2009) but also in sheep (Lock et al., 2006). However, the very low levels and the lack of variation in this isomer (Table 3; Figure 2) would suggest that other inhibitors of milk fat synthesis should also be involved. Furthermore, greater increases in trans-10, cis-12 CLA in the absence of MFD have previously been reported in dairy sheep fed either low- or high-concentrate diets (Reynolds et al., 2006; Gómez-Cortés et al., 2008a; Hervás et al., 2008).

Postruminal infusion experiments have provided tentative evidence that cis-10,trans-12 and trans-9,cis-11 CLA also exert antilipogenic effects (Perfield et al., 2007; Harvatine et al., 2009). The former FA was not detected in the present study, but the remarkable in- 
Table 3. Fatty acid (FA) profile of the milk from ewes fed the experimental diets

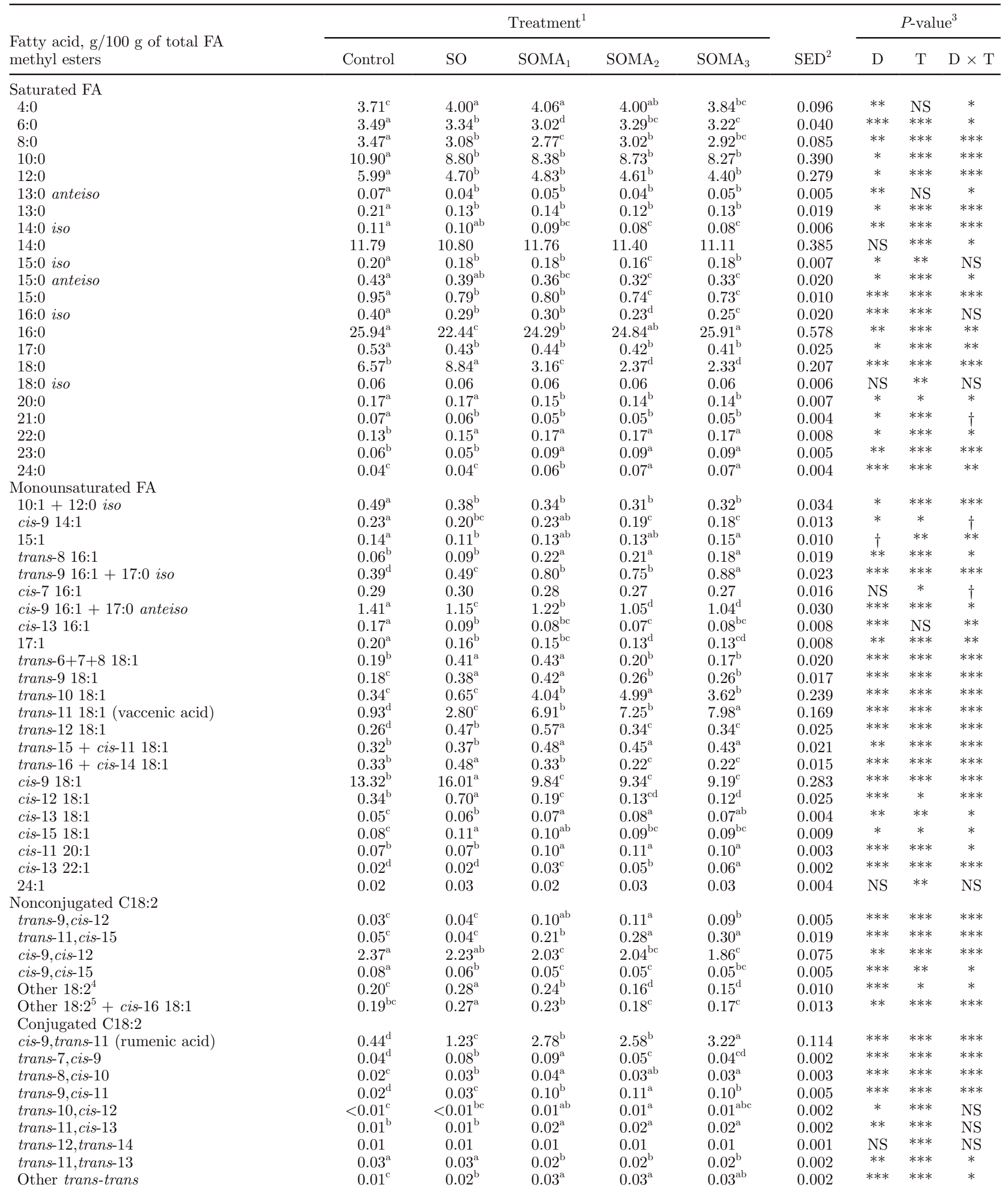


Table 3 (Continued). Fatty acid (FA) profile of the milk from ewes fed the experimental diets

\begin{tabular}{|c|c|c|c|c|c|c|c|c|c|}
\hline $\begin{array}{l}\text { Fatty acid, } \mathrm{g} / 100 \mathrm{~g} \text { of total FA } \\
\text { methyl esters }\end{array}$ & \multicolumn{5}{|c|}{ Treatment $^{1}$} & $\mathrm{SED}^{2}$ & \multicolumn{3}{|c|}{$P$-value ${ }^{3}$} \\
\hline $16: 2 \mathrm{n}-6$ & $0.02^{\mathrm{b}}$ & $0.02^{\mathrm{b}}$ & $0.05^{\mathrm{a}}$ & $0.06^{\mathrm{a}}$ & $0.06^{\mathrm{a}}$ & 0.005 & $* * *$ & $* * *$ & * \\
\hline $18: 3 n-6$ & $0.08^{\mathrm{a}}$ & $0.06^{\mathrm{b}}$ & $0.06^{\mathrm{b}}$ & $0.05^{\mathrm{b}}$ & $0.05^{\mathrm{b}}$ & 0.004 & $* * *$ & $* * *$ & $*$ \\
\hline $18: 3 n-3$ & $0.53^{\mathrm{a}}$ & $0.41^{\mathrm{b}}$ & $0.37^{\mathrm{c}}$ & $0.36^{\mathrm{c}}$ & $0.34^{\mathrm{d}}$ & 0.013 & $* * *$ & $\dagger$ & NS \\
\hline cis-9,trans-11,cis-15 18:3 & 0.03 & 0.03 & 0.03 & 0.03 & 0.03 & 0.003 & NS & ** & NS \\
\hline $20: 3 n-3$ & $0.02^{\mathrm{bc}}$ & $0.01^{\mathrm{c}}$ & $0.02^{\mathrm{ab}}$ & $0.02^{\mathrm{ab}}$ & $0.03^{\mathrm{a}}$ & 0.003 & $*$ & $*$ & $\dagger$ \\
\hline $20: 4 n-6$ & $0.16^{\mathrm{c}}$ & $0.12^{\mathrm{d}}$ & $0.17^{\mathrm{bc}}$ & $0.20^{\mathrm{b}}$ & $0.24^{\mathrm{a}}$ & 0.014 & $* *$ & $* * *$ & $* * *$ \\
\hline 20:5 n-3 (eicosapentaenoic acid) & $0.05^{\mathrm{c}}$ & $0.04^{\mathrm{c}}$ & $0.05^{\mathrm{c}}$ & $0.09^{\mathrm{b}}$ & $0.10^{\mathrm{a}}$ & 0.004 & $* * *$ & $* * *$ & $* * *$ \\
\hline $22: 4 \mathrm{n}-6$ & $0.03^{\mathrm{d}}$ & $0.03^{\mathrm{d}}$ & $0.04^{\mathrm{c}}$ & $0.05^{\mathrm{b}}$ & $0.05^{\mathrm{a}}$ & 0.001 & $* * *$ & $* * *$ & $* *$ \\
\hline $22: 5 \mathrm{n}-6$ & $0.01^{\mathrm{d}}$ & $0.02^{\mathrm{d}}$ & $0.11^{\mathrm{c}}$ & $0.28^{\mathrm{b}}$ & $0.33^{\mathrm{a}}$ & 0.014 & $* * *$ & $* * *$ & *** \\
\hline $22: 5$ n-3 (docosapentaenoic acid) & $0.10^{\mathrm{c}}$ & $0.07^{\mathrm{d}}$ & $0.10^{\mathrm{c}}$ & $0.13^{\mathrm{b}}$ & $0.15^{\mathrm{a}}$ & 0.004 & $* * *$ & $* * *$ & $* * *$ \\
\hline $22: 6 \mathrm{n}-3$ (docosahexaenoic acid) & $0.03^{\mathrm{d}}$ & $0.02^{\mathrm{d}}$ & $0.17^{\mathrm{c}}$ & $0.46^{\mathrm{b}}$ & $0.57^{\mathrm{a}}$ & 0.021 & $* * *$ & $* * *$ & $* * *$ \\
\hline
\end{tabular}

${ }^{\mathrm{a}-\mathrm{d}}$ Means within a row with different superscripts differ significantly.

${ }^{1}$ Diets included a TMR without lipid supplementation (control) or supplementation with $25 \mathrm{~g}$ of sunflower oil/kg of DM plus 0 (SO), 8 (SOMA 1 ), $16\left(\mathrm{SOMA}_{2}\right)$, or $24\left(\mathrm{SOMA}_{3}\right) \mathrm{g}$ of marine algae $(56.7 \%$ ether extract $) / \mathrm{kg}$ of DM.

${ }^{2} \mathrm{SED}=$ standard error of the difference.

${ }^{3}$ Probability of significant effects of experimental diet (D), time on $\operatorname{diet}(\mathrm{T})$, and their interaction $(\mathrm{D} \times \mathrm{T})$. NS $=$ not significant $(P>0.10)$.

${ }^{4}$ trans -9, trans- $12+$ cis- 9, trans- $13+$ trans-8, cis- 12 C18:2.

${ }^{5}$ trans- 8, cis- $13+$ cis- 9, trans- 12 C18:2.

$\dagger P<0.10 ;{ }^{*} P<0.05 ;{ }^{* *} P<0.01 ; * * * P<0.001$.

creases in trans-9,cis-11 C18:2 could partially explain the MFD arising in ewes consuming SOMA diets. Previous evidence in cows (Roy et al., 2006; Perfield et al., 2007) indicates that this CLA isomer inhibits milk fat synthesis, but with a much lower efficacy than trans10, cis-12 C18:2.

The inverse relationship between milk fat yield and trans-10 C18:1 ( $\mathrm{r}=-0.71 ; P<0.001)$ might suggest that this FA is another candidate for the inhibition of milk fat synthesis. However, a 4-d abomasal infusion of $40 \mathrm{~g} / \mathrm{d}$ of this trans-C18:1 isomer was not effective in reducing the milk fat percentage in cows (Lock et al. 2007), which may be the result of the low enrichment of trans-10 C18:1 during infusions (Kadegowda et al., 2008). A more recent study (Kadegowda et al., 2009) supports the idea that trans-10 C18:1 reaching the mammary gland could potentially induce MFD by decreasing lipogenic gene expression. Furthermore, infusions of approximately $90 \mathrm{~g} / \mathrm{d}$ of trans-10 C18:1 for a 5-d period reduced milk fat secretion, although the authors (Shingfield et al., 2009) suggest that this trans-FA was about 40- to 50-fold less effective than trans-10,cis-12 C18:2. Interestingly, in that study, the level of milk trans-10 C18:1 was about $4 \%$, similar to that observed here for SOMA diets (Table 3). However, it is noteworthy that higher levels (about 6\%) have previously been found in dairy ewes supplemented with vegetable oils without concomitant reductions in milk fat (Gómez-Cortés et al., 2008a; Hervás et al., 2008), which would rule out trans-10 C18:1 as the principal factor responsible for the reduction observed in milk fat content.

The high correlation between trans-10 C18:1 and trans-9,cis-11 C18:2 ( $\mathrm{r}=0.93 ; P<0.001)$ might support the hypothesis that they have a common precursor or are produced by a common rumen bacteria (Roy et al., 2006; Shingfield et al., 2006; Gama et al., 2008), and although the low concentration of trans-9,cis-11 CLA makes it unlikely that it may be the principal component responsible for MFD (Perfield et al., 2007), trans-9, cis-11 CLA and milk fat content were also negatively correlated $(\mathrm{r}=-0.78 ; P<0.001)$. Accordingly, a joint action of trans-9,cis-11 C18:2 and trans-10 C18:1, together with that of other unidentified intermediates, would seem to be a feasible explanation for MFD in SOMA treatments (Perfield et al., 2007; Kadegowda et al., 2008, 2009; Shingfield et al., 2009), but mechanisms other than direct inhibition may also be involved. In this regard, several authors have speculated about an effect of the maintenance of milk fat fluidity on milk fat secretion (Shingfield et al., 2006; Chilliard et al., 2007; Gama et al., 2008) related to the incorporation of oleic acid and short-chain FA (C4:0-C10:0) into triglycerides as the principal means of ensuring milk fat liquidity at body temperature (Timmen and Patton, 1988). Thus, the known inhibition of marine lipids on $\mathrm{C} 18: 1$ ruminal saturation (Or-Rashid et al., 2008), reducing therefore the availability of C18:0 for endogenous mammary synthesis of oleic acid, plus the contribution of decreased de novo FA synthesis, would detrimentally affect the 
TORAL ET AL.
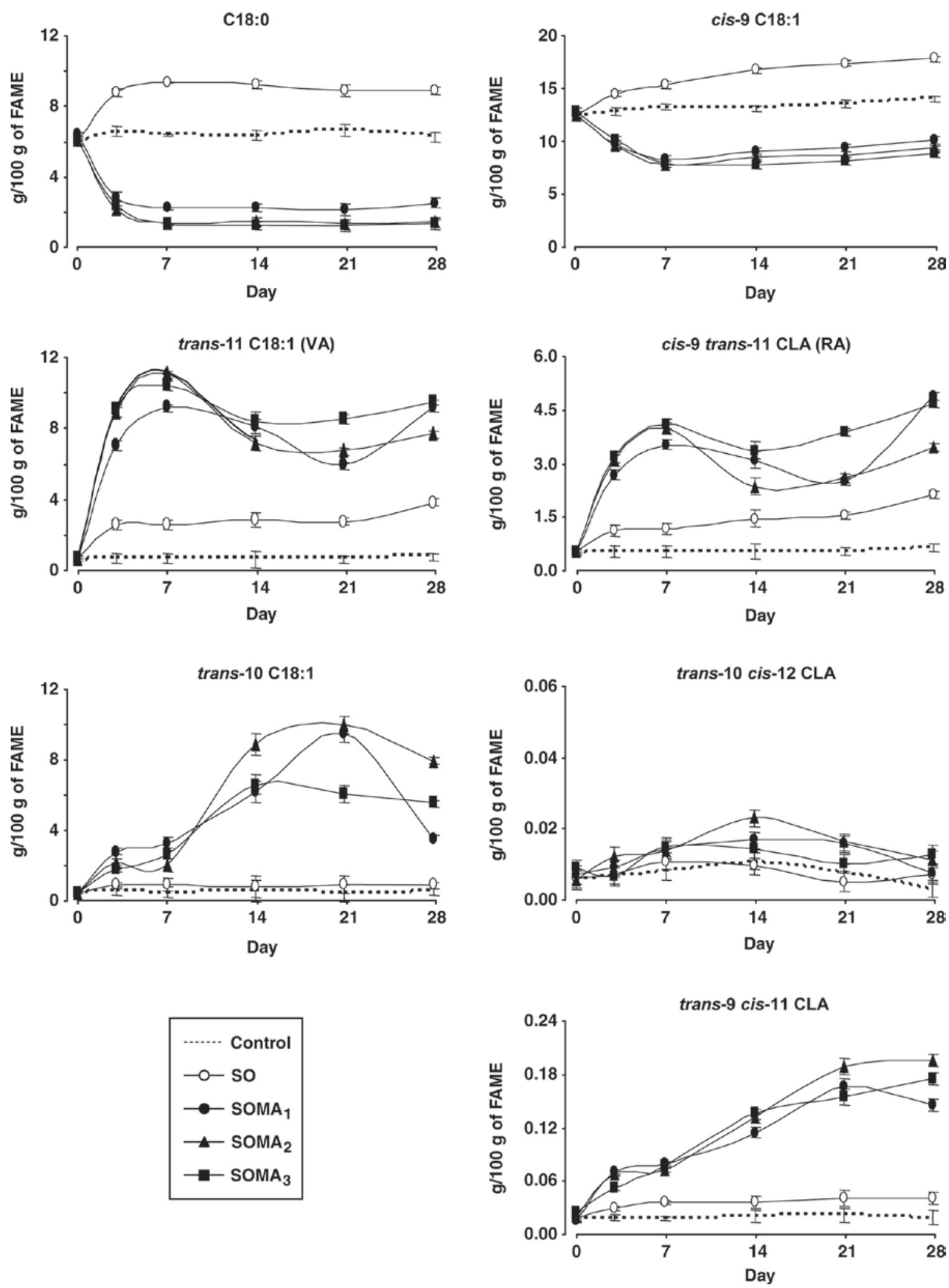

Figure 2. Temporal changes in C18:0, cis-9 C18:1, trans-11 C18:1, cis-9,trans-11 CLA, trans-10 C18:1, trans-10,cis-12 CLA, and trans9,cis-11 CLA (g/100 g of fatty acids methyl esters) in ewes fed a TMR without lipid supplementation (control) or supplemented with $25 \mathrm{~g}$ of sunflower oil $/ \mathrm{kg}$ of DM plus $0,8,16$, or $24 \mathrm{~g}$ of marine algae $/ \mathrm{kg}$ of DM (SO, SOMA $1, \mathrm{SOMA}_{2}$, and $\mathrm{SOMA}_{3}$ diets, respectively). Values are the mean from 2 lots of 5 animals per lot; vertical bars represent the standard error of the means. CLA = conjugated linoleic acid; RA $=$ rumenic acid. 
Table 4. Fatty acid (FA) composition, indices of desaturase activity, n-6:n-3 ratio, and melting point of the milk from ewes fed the experimental diets

\begin{tabular}{|c|c|c|c|c|c|c|c|c|c|}
\hline \multirow[b]{2}{*}{ Fatty acid composition, $\mathrm{g} / 100 \mathrm{~g}$ of FA methyl esters } & \multicolumn{5}{|c|}{ Treatment $^{1}$} & \multirow[b]{2}{*}{$\mathrm{SED}^{2}$} & \multicolumn{3}{|c|}{$P$-value ${ }^{3}$} \\
\hline & Control & $\mathrm{SO}$ & $\mathrm{SOMA}_{1}$ & $\mathrm{SOMA}_{2}$ & $\mathrm{SOMA}_{3}$ & & $\mathrm{D}$ & $\mathrm{T}$ & $\mathrm{D} \times \mathrm{T}$ \\
\hline \multicolumn{10}{|l|}{ According to degree of saturation } \\
\hline Saturated FA & $75.40^{\mathrm{a}}$ & $69.00^{\mathrm{b}}$ & $65.07^{\mathrm{c}}$ & $65.01^{\mathrm{c}}$ & $64.91^{\mathrm{c}}$ & 0.383 & $* * *$ & $* * *$ & $* * *$ \\
\hline Monounsaturated FA & $19.73^{\mathrm{d}}$ & $25.48^{\mathrm{c}}$ & $26.98^{\mathrm{a}}$ & $26.54^{\mathrm{ab}}$ & $25.90^{\mathrm{bc}}$ & 0.312 & *** & $* * *$ & $* * *$ \\
\hline Polyunsaturated FA & $4.50^{\mathrm{d}}$ & $5.47^{\mathrm{c}}$ & $7.82^{\mathrm{b}}$ & $8.03^{\mathrm{b}}$ & $8.91^{\mathrm{a}}$ & 0.120 & $* * *$ & $* * *$ & $* * *$ \\
\hline \multicolumn{10}{|l|}{ According to origin ${ }^{4}$} \\
\hline$<\mathrm{C} 16$ & $42.60^{\mathrm{a}}$ & $37.18^{\mathrm{b}}$ & $37.07^{\mathrm{b}}$ & $37.25^{\mathrm{b}}$ & $36.14^{\mathrm{b}}$ & 0.977 & ** & $* * *$ & $* * *$ \\
\hline C16 & $28.65^{\mathrm{ab}}$ & $24.92^{\mathrm{c}}$ & $27.31^{\mathrm{b}}$ & $27.51^{\mathrm{ab}}$ & $28.79^{\mathrm{a}}$ & 0.524 & ** & $* * *$ & $* * *$ \\
\hline$>\mathrm{C} 16$ & $29.00^{\mathrm{c}}$ & $37.80^{\mathrm{a}}$ & $35.61^{\mathrm{b}}$ & $35.24^{\mathrm{b}}$ & $35.08^{\mathrm{b}}$ & 0.581 & $* * *$ & $* * *$ & $* * *$ \\
\hline \multicolumn{10}{|l|}{ Desaturase index } \\
\hline cis-9 C14:1/(C14:0 + cis-9 C14:1) & $0.019^{\mathrm{a}}$ & $0.019^{\mathrm{a}}$ & $0.019^{\mathrm{a}}$ & $0.017^{\mathrm{b}}$ & $0.015^{\mathrm{b}}$ & 0.0009 & ** & $* * *$ & $\dagger$ \\
\hline cis-9 C16:1/(C16:0 + cis-9 C16:1) & $0.051^{\mathrm{a}}$ & $0.049^{\mathrm{ab}}$ & $0.046^{\mathrm{bc}}$ & $0.044^{\mathrm{c}}$ & $0.040^{\mathrm{d}}$ & 0.0114 & ** & $* * *$ & $*$ \\
\hline cis-9 C18:1/(C18:0 + cis-9 C18:1) & $0.670^{\mathrm{c}}$ & $0.645^{\mathrm{d}}$ & $0.768^{\mathrm{b}}$ & $0.817^{\mathrm{a}}$ & $0.820^{\mathrm{a}}$ & 0.0043 & $* * *$ & $* * *$ & $* * *$ \\
\hline cis-9,trans-11 C18:2/(trans-11 C18:1 + cis-9,trans-11 C18:2) & $0.321^{\mathrm{a}}$ & $0.287^{\mathrm{b}}$ & $0.264^{\mathrm{c}}$ & $0.267^{\mathrm{c}}$ & $0.327^{\mathrm{a}}$ & 0.0073 & *** & $* * *$ & $* * *$ \\
\hline n-6:n-3 ratio & $3.47^{\mathrm{b}}$ & $4.21^{\mathrm{a}}$ & $3.27^{\mathrm{b}}$ & $2.42^{\mathrm{c}}$ & $2.12^{\mathrm{c}}$ & 0.119 & $* * *$ & $* * *$ & $* * *$ \\
\hline Milk melting point, ${ }^{\circ} \mathrm{C}$ & $34.6^{\mathrm{b}}$ & $34.0^{\mathrm{c}}$ & $35.1^{\mathrm{a}}$ & $34.5^{\mathrm{b}}$ & $34.6^{\mathrm{b}}$ & 0.14 & $* * *$ & $* * *$ & $*$ \\
\hline
\end{tabular}

${ }^{\mathrm{a}-\mathrm{d}}$ Means within a row with different superscripts differ significantly.

${ }^{1}$ Diets included a TMR without lipid supplementation (control) or supplementation with $25 \mathrm{~g}$ of sunflower oil/kg of DM plus 0 (SO), 8 (SOMA $)$, 16 ( $\mathrm{SOMA}$ ), or 24 (SOMA $\mathrm{SOM}_{3}$ of marine algae $(56.7 \%$ ether extract) $/ \mathrm{kg}$ of DM.

${ }^{2} \mathrm{SED}=$ standard error of the difference.

$\stackrel{\complement}{{ }_{0}^{3}}$ Probability of significant effects of experimental diet (D), time on diet $(\mathrm{T})$, and their interaction $(\mathrm{D} \times \mathrm{T})$. NS $=$ not significant $(P>0.10)$.

${ }^{4}<\mathrm{C} 16$ represent de novo synthesized FA, $>$ C16 represent preformed FA taken up from circulation, and C16 FA are derived from both sources.

$\dagger P<0.10 ;{ }^{*} P<0.05 ;{ }^{* *} P<0.01 ;{ }^{* * *} P<0.001$. 

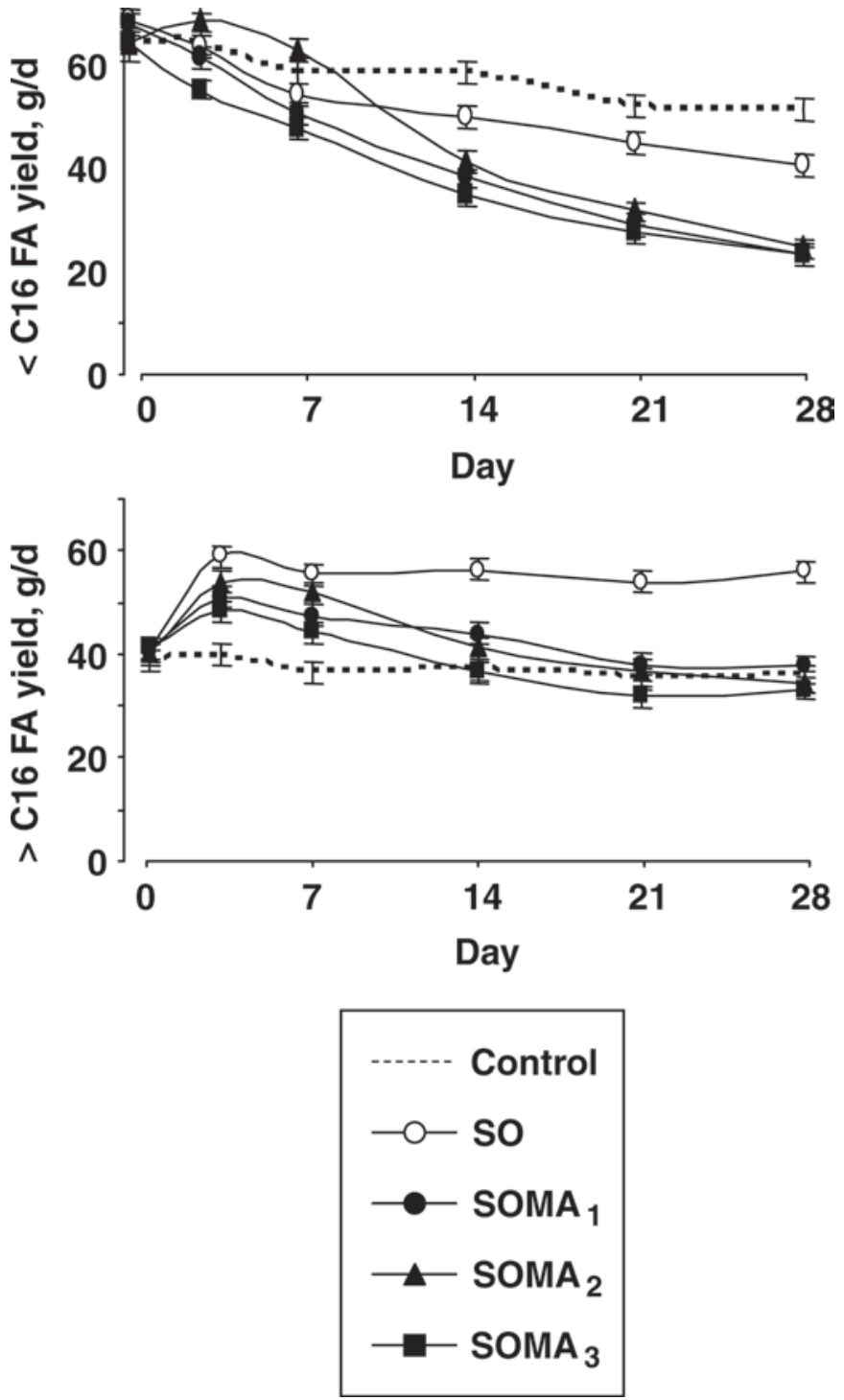

Figure 3. Temporal changes in $<\mathrm{C} 16$ and $>\mathrm{C} 16$ fatty acid yield (g/d) in ewes fed a TMR without lipid supplementation (control) or supplemented with $25 \mathrm{~g}$ of sunflower oil $(\mathrm{SO}) / \mathrm{kg}$ of DM plus $0,8,16$ or $24 \mathrm{~g}$ of marine algae (MA) $/ \mathrm{kg}$ of DM $\left(\mathrm{SO}, \mathrm{SOMA}_{1}, \mathrm{SOMA}_{2}\right.$, and $\mathrm{SOMA}_{3}$ diets, respectively). Values are the mean from 2 lots of 5 animals per lot; vertical bars represent the standard error of the means.

maintenance of milk fat liquidity at body temperature. Moreover, the augmentation in trans-FA (mainly C18:1 isomers), with higher melting points than their equivalent cis-isomers (Gunstone et al., 1994), might also contribute to reduce milk fat fluidity because milk fat globules with melting points higher than body temperature could not be secreted (Timmen and Patton, 1988; Gama et al., 2008). Major changes in milk FA composition induced numerically minor variations in calculated milk fat melting point (between -0.7 and $+0.7^{\circ} \mathrm{C}$; Table 4 ), even lower than those reported in the milk of cows fed fish oil (Gama et al., 2008), which gives an idea of the high regulatory capacity of the mammary gland.

Furthermore, the activity of the $\Delta^{9}$-desaturase in the mammary gland of ruminants is also thought to occur as a mechanism to maintain and regulate the fluidity of milk fat for efficient secretion. Although significant differences were observed for all the calculated desaturase indices (Table 4), only changes in cis-9 C18:1/(C18:0 + cis-9 C18:1) were of quantitative importance. According to Gama et al. (2008), this could be attributable to either an increase in the specific activity of $\Delta^{9}$-desaturase for stearic acid when feeding marine lipids or a higher uptake of oleic acid coming from adipose tissues. Both responses may result from a physiological adaptation to the increased supply of trans-C18:1 FA and the decline in the stearic acid uptake and availability for mammary oleic acid synthesis.

In addition, as previously reported for CLA-induced MFD (Lock et al., 2006; Harvatine et al., 2009), lipid supplements reduced the milk content of FA with fewer than $16 \mathrm{C}$ (i.e., synthesized de novo in the mammary gland) and increased those with more than $16 \mathrm{C}$ (i.e., originated from mammary uptake of circulating FA), suggesting further mechanisms by which the mammary gland can adapt to altered supply of FA. To give a clearer insight into changes in mammary fat secretion, data of de novo and preformed FA yields are shown in Figure 3. Thus, when SO was fed alone, reduced de novo FA yield (from d 14 onward; $P<0.05$ ) was alleviated by an increase in the secretion of $>\mathrm{C} 16 \mathrm{FA}$ $(P<0.01)$. However, the greater decrease in $<$ C16 FA yield induced by the addition of MA $(P<0.05)$ was not compensated for by the transient increase in long-chain FA yield.

\section{Saturated and Monoenoic FA}

It is now well established that increases in the supply of long-chain FA to the mammary gland alter the synthesis of short- and medium-chain saturates (Pulina et al., 2006; Chilliard et al., 2007; Kadegowda et al., 2009). Because high intakes of saturated FA could be related to an increased risk of cardiovascular disease and development of the metabolic syndrome (Shingfield et al., 2008), the effect of SO and MA supplementation (Table 4) would have a positive effect on the nutritional value of milk fat. It is, however, noteworthy that the specific role of saturated FA should be considered individually in relation to their putative effect on human health (see review by Shingfield et al., 2008).

The decrease in C18:0 and cis-9 C18.1 together with the increase in trans-C18:1 in SOMA diets milk fat would reflect the inhibitory action of the long-chain n-3 PUFA present in MA, mainly DHA (AbuGhazaleh 
and Jenkins, 2004), on trans-C18:1 ruminal reduction (Loor et al., 2005; Sinclair et al., 2005; Or-Rashid et al., 2008). As a consequence, SOMA treatments resulted in the greatest percentage of trans-C18:1, mainly VA and trans-10, 2 intermediaries of linoleic acid BH pathways (Jenkins et al., 2008). Other minor trans-C18:1 (trans $-6+7+8$, trans-9, and trans-12) could also derive from isomerization of oleic acid (26\% of total FA in sunflower oil) because $\mathrm{BH}$ of this latter $\mathrm{FA}$ involves the formation of several isomers of trans-monoenes further to trans-10 and trans-11 C18:1 (Jenkins et al., 2008).

High contents of VA in bovine milk are better maintained with high levels of forage, or low lipid supplementation, or both (Palmquist et al., 2005; Chilliard et al., 2007; Cruz-Hernández et al., 2007), whereas addition of marine lipids or linoleic oil- and starch-rich diets have been related to a shift in ruminal $\mathrm{BH}$ toward increased formation of trans-10 C18:1 at the expense of VA (Roy et al., 2006; Chilliard et al., 2007; OrRashid et al., 2008). It is remarkable that high levels of trans-10 C18:1 in ovine milk appear to be accompanied by similar or even higher contents of VA (Reynolds et al., 2006), whereas in dairy cows, there is a pronounced inverse relationship between these $2 \mathrm{FA}$, so the trans-10 C18:1 content may amply exceed that of VA (Roy et al., 2006; Shingfield et al., 2006; Boeckaert et al., 2008). This highlights the importance of interspecific differences among dairy ruminants, as has been stated in the case of goats and cows (Chilliard et al., 2007). Even though notable and greater trans-10 C18:1 levels were previously achieved in dairy ewes with the inclusion of linoleic-rich oils in high-starch diets (Gómez-Cortés et al., 2008a; Hervás et al., 2008), an adequate fiber content probably prevented altered ruminal biohydrogenation toward trans-10 C18:1 ruminal formation in the SO treatment but not in MA-containing diets (Roy et al., 2006; Shingfield et al., 2006), where rumen environment might be altered by MA. This hypothesis would be in line with the decrease of branched- and odd-chain FA contents observed mainly in MA treatments. Unexpectedly, the high trans-10 C18:1 concentration observed in SOMA treatments decreased significantly in $\mathrm{SOMA}_{1}$ on $\mathrm{d} 28$, which might indicate adaptation of the rumen microbiota to MA consumption. This speculation could be supported by the concomitant variations in trans9, cis-11 CLA (decrease) and VA and RA (increases) and the slight recovery in milk fat content.

\section{Conjugated and Nonconjugated Linoleic Acid}

Because of the transient nature of RA formed in the rumen, endogenous synthesis from VA through mammary $\Delta^{9}$-desaturase is considered the principal origin of this CLA isomer in ruminant milk (Palmquist et al., 2005; Pulina et al., 2006; Shingfield et al., 2008). Thus, those diets inducing the largest accumulation of VA resulted also in the highest milk RA concentrations ( $\mathrm{r}$ $=0.97 ; P<0.001$ ). Temporal variations in RA (Figure 1) contrast with the situation in dairy cows, where a progressive, time-dependent reduction in this FA is frequently found after initial increases following lipid supplementation of starch-rich diets (Shingfield et al., 2006; Chilliard et al., 2007).

Changes in nonconjugated C18:2 were less remarkable, and although mean intake of linoleic acid increased by $53 \mathrm{~g} / \mathrm{d}$ with lipid supplementation, its concentration in milk fat was unmodified with $\mathrm{SO}$ and even decreased with SOMA treatments, probably because the usually high ruminal $\mathrm{BH}$ of linoleic acid can be further increased with marine lipid supplements (up to $90 \%$ according to Sinclair et al., 2005). The notable rise in milk trans-C18:1 would also support this hypothesis.

Regarding other nonconjugated C18:2 FA detected in milk fat, trans-11, cis-15 C18:2 was the most extensively modified by lipid supplementation, reaching on average a 6-fold increase with $\mathrm{SOMA}_{2}$ and $\mathrm{SOMA}_{3}(0.30 \%$ of total FA). Identified as an intermediate of C18:3 n-3 ( $\alpha$-linolenic acid) metabolism (Jenkins et al., 2008), its content is frequently greater in milk fat when marine oils are fed (Shingfield et al., 2006; Chilliard et al., 2007), which suggests a putative inhibitory effect of MA long-chain n-3 PUFA on the complete $\mathrm{BH}$ process of $\alpha$-linolenic acid (Loor et al., 2005).

\section{Other Polyunsaturated FA}

Diet supplementation with SO plus MA offered some additional changes pointing toward a healthier milk FA profile, such as the dose-dependent improvement in DHA concentration and the decrease in the $n-6: n-3$ FA ratio, of great importance in reducing the risk of cardiovascular diseases (Simopoulos, 2008). However, despite the high DHA content of the MA supplement ( $42 \%$ of total FA), these increases appear limited and represented an average transfer efficiency of only $5 \%$, in line with transferences observed by other authors in cows and sheep (Papadopoulos et al., 2002; Loor et al., 2005; Chilliard et al., 2007) but lower than some previous reports in dairy ewes (Reynolds et al., 2006; Capper et al., 2007). The ruminal BH of long-chain n-3 PUFA (Loor et al., 2005; Sinclair et al., 2005; CastañedaGutiérrez et al., 2007) may partially account for their low transfer efficiencies into milk. Preferential partitioning of n-3 PUFA into some plasma lipid fractions that are poorly taken up by the mammary gland, such as plasma cholesterol ester and phospholipids (Offer et 
al., 1999; Kitessa et al., 2001; Chilliard et al., 2007), would also help to explain these results.

\section{CONCLUSIONS}

Supplementation of the diet of ewes with 3 incremental levels of MA and a moderate amount of SO affected animal performance by reducing the milk content of fat and protein, even with the lowest level of MA inclusion. Although all lipid supplements lowered the yield of FA originating from de novo synthesis $(<\mathrm{C} 16)$, sustained increase in the output of long-chain FA prevented MFD when only SO was added. Marine algae-induced MFD might have been related to the joint action of some putative fat synthesis inhibitors, such as trans-9, cis-11 CLA and probably trans-10 C18:1, as well as to the effect on milk fat fluidity of the decrease in C18:0 and subsequently in cis-9 C18:1 content together with the rise in trans-FA contents. The combination of $\mathrm{SO}$ and MA, especially with the highest level of the latter, proved to be very effective for improving the milk concentration of some bioactive components, such as RA, VA, and DHA, and reducing the n-6:n-3 FA ratio. However, despite changes induced by SOMA supplementation in the milk FA profile that pointed to an enhanced nutritional value of the milk fat, large increases in other trans-FA, mainly trans-10 C18:1, were also observed.

\section{ACKNOWLEDGMENTS}

This work was supported by the Ministerio de Ciencia e Innovación (MICINN; AGL2008-04805). The authors from the Instituto de Ganadería de Montaña (León, Spain) thank the research farm staff for their help in the field work. P. G. Toral gratefully acknowledges receipt of a predoctoral grant from the CSIC (I3P Programme). The authors from the Instituto del Frío (CSIC, Madrid, Spain) thank the Comunidad Autónoma de Madrid (S2009-AGR-1549) and the Ministerio de Ciencia e Innovación (Consolider Ingenio 2010 Programme; FUNC-FOOD CSD2007-063) for their financial support. They also thank M. V. Rodríguez-Pino (Instituto del Frío, Madrid, Spain) for her technical assistance with the chromatographic analysis.

\section{REFERENCES}

AbuGhazaleh, A. A., and T. C. Jenkins. 2004. Docosahexaenoic acid promotes vaccenic acid accumulation in mixed rumen cultures when incubated with linoleic acid. J. Dairy Sci. 87:1047-1050.

Ankom. 2006a. Acid detergent fiber in feeds. Filter bag technique (for A2000, A2000I). Ankom Technology Method 8. Ankom Technology Corp., Macedon, NY
Ankom. 2006b. Neutral detergent fiber in feeds. Filter bag technique (for A2000, A2000I). Ankom Technology Method 9. Ankom Technology Corp., Macedon, NY.

AOCS. 2008. Official Methods and Recommended Practices of the American Oil Chemist's Society. 5th ed. AOCS, Urbana, IL.

Boeckaert, C., B. Vlaeminck, J. Dijkstra, A. Issa-Zacharia, T. Van Nespen, W. Van Straalen, and V. Fievez. 2008. Effect of dietary starch or micro algae supplementation on rumen fermentation and milk fatty acid composition of dairy cows. J. Dairy Sci. 91:47144727

Capper, J. L., R. G. Wilkinson, A. M. Mackenzie, and L. A. Sinclair. 2007. The effect of fish oil supplementation of pregnant and lactating ewes on milk production and lamb performance. Animal $1: 889-898$.

Castañeda-Gutiérrez, E., M. J. de Veth, A. L. Lock, D. A. Dwyer, K. D. Murphy, and D. E. Bauman. 2007. Effect of supplementation with calcium salts of fish oil on n-3 fatty acids in milk fat. J. Dairy Sci. 90:4149-4156.

Chilliard, Y., F. Glasser, A. Ferlay, L. Bernard, J. Rouel, and M. Doreau. 2007. Diet, rumen biohydrogenation and nutritional quality of cow and goat milk fat. Eur. J. Lipid Sci. Technol. 109:828-855.

Cruz-Hernández, C., J. K. G. Kramer, J. J. Kennelly, D. R. Glimm, B. M. Sorensen, E. K. Okine, L. A. Goonewardene, and R. J. Weselake. 2007. Evaluating the conjugated linoleic acid and trans 18:1 isomers in milk fat of dairy cows fed increasing amounts of sunflower oil and a constant level of fish oil. J. Dairy Sci. 90:3786-3801

Franklin, S. T., K. R. Martin, R. J. Baer, D. J. Schingoethe, and A. R. Hippen. 1999. Dietary marine algae (Schizochytrium sp.) increases concentrations of conjugated linoleic, docosahexaenoic and transvaccenic acids in milk of dairy cows. J. Nutr. 129:2048 2054.

Gama, M. A. S., P. C. Garnsworthy, J. M. Griinari, P. R. Leme, P. H. M. Rodrigues, L. W. O. Souza, and D. P. D. Lanna. 2008 Diet-induced milk fat depression: Association with changes in milk fatty acid composition and fluidity of milk fat. Livest. Sci. 115:319-331.

Gómez-Cortés, P., P. Frutos, A. R. Mantecón, M. Juárez, M. A. de la Fuente, and G. Hervás. 2008b. Addition of olive oil to dairy ewe diet: Effect on milk fatty acid profile and animal performance. J. Dairy Sci. 91:3119-3127.

Gómez-Cortés, P., G. Hervás, A. R. Mantecón, M. Juárez, M. A. de la Fuente, and P. Frutos. 2008a. Milk production, CLA content, and in vitro ruminal fermentation in response to high levels of soybean oil in dairy ewe diet. J. Dairy Sci. 91:1560-1569.

Griinari, J. M., and D. Bauman. 2006. Milk fat depression: Concepts, mechanisms and management applications. Pages 389-417 in Ruminant Physiology: Digestion, Metabolism and Impact of Nutrition on Gene Expression, Immunology and Stress. K. Sjersen, T. Hvelplund, and M. O. Nielsen, ed. Wageningen Acad. Publ., Wageningen, the Netherlands.

Gunstone, F. D., J. L. Harwood, and F. B. Padley. 1994. The Lipid Handbook. 2nd ed. Chapman and Hall, New York, NY.

Harvatine, K. J., Y. R. Boisclair, and D. E. Bauman. 2009. Recent advances in the regulation of milk fat synthesis. Animal 3:4054.

Hervás, G., P. Luna, A. R. Mantecón, N. Castañares, M. A. de la Fuente, M. Juárez, and P. Frutos. 2008. Effect of diet supplementation with sunflower oil in milk production, fatty acid profile and ruminal fermentation in lactating ewes. J. Dairy Res. 75:399-405.

ISO. 1999a. Animal feeding stuffs-Determination of moisture and other volatile matter content. International Standard ISO 6496:1999. International Organisation for Standardisation (ISO), Geneva, Switzerland.

ISO. 1999b. Whole milk - Determination of milkfat, protein and lactose content: Guidance on the operation of mid-infrared instruments. International Standard ISO 9622:1999. International Organisation for Standardisation (ISO), Geneva, Switzerland. 
ISO. 2002a. Animal feeding stuffs-Determination of crude ash. International Standard ISO 5984:2002. International Organisation for Standardisation (ISO), Geneva, Switzerland.

ISO. 2002b. Milk fat-Preparation of fatty acid methyl esters. International Standard ISO 15884:2002. International Organisation for Standardisation (ISO), Geneva, Switzerland.

ISO. 2005. Animal feeding stuffs - Determination of nitrogen content and calculation of crude protein content; Part 2: Block digestion and steam distillation method. International Standard ISO 59832:2005. International Organisation for Standardisation (ISO), Geneva, Switzerland.

Jenkins, T. C., R. J. Wallace, P. J. Moate, and E. E. Mosley. 2008. Recent advances in biohydrogenation of unsaturated fatty acids within the rumen microbial ecosystem. J. Anim. Sci. 86:397412.

Jensen, R. G., and S. Patton. 2000. The effect of maternal diets on the mean melting points of human milk fatty acids. Lipids 35:11591161.

Kadegowda, A. K. G., M. Bionaz, L. S. Piperova, R. A. Erdman, and J. J. Loor. 2009. Peroxisome proliferators-activated receptoractivation and long-chain fatty acids alter lipogenic gene networks in bovine mammary epithelial cells to various extents. J. Dairy Sci. 92:4276-4289.

Kadegowda, A. K. G., L. S. Piperova, and R. A. Erdman. 2008 Principle component and multivariate analysis of milk long-chain fatty acid composition during diet-induced milk fat depression. J. Dairy Sci. 91:749-759.

Kitessa, S. M., S. K. Gulati, J. R. Ashes, E. Fleck, T. W. Scott, and P. D. Nichols. 2001. Utilisation of fish oil in ruminants. I. Fish oil metabolism in sheep. Anim. Feed Sci. Technol. 89:189-199.

Lock, A. L., B. M. Teles, J. W. Perfield, D. E. Bauman, and L. A. Sinclair. 2006. A conjugated linoleic acid supplement containing trans-10, cis-12 reduces milk fat synthesis in lactating sheep. J. Dairy Sci. 89:1525-1532.

Lock, A. L., C. Tyburczy, D. A. Dwyer, K. J. Harvatine, F. Destaillats, Z. Mouloungui, L. Candy, and D. E. Bauman. 2007. Trans-10 octadecenoic acid does not reduce milk fat synthesis in dairy cows. J. Nutr. 137:71-76.

Loor, J. J., M. Doreau, J. M. Chardigny, A. Ollier, J. L. Sebedio, and Y. Chilliard. 2005. Effects of ruminal or duodenal supply of fish oil on milk fat secretion and profiles of trans-fatty acids and conjugated linoleic acid isomers in dairy cows fed maize silage. Anim. Feed Sci. Technol. 119:227-246.

Luna, P., M. Juárez, and M. A. de la Fuente. 2005. Validation of a rapid milk fat separation method to determine the fatty acid profile by gas chromatography. J. Dairy Sci. 88:3377-3381.

Offer, N. W., M. Marsden, J. Dixon, B. K. Speake, and F. E. Thacker. 1999. Effect of dietary fat supplements on levels of n-3 polyunsaturated fatty acids, trans acids and conjugated linoleic acid in bovine milk. Anim. Sci. 69:613-625.

Offer, N. W., M. Marsden, and R. H. Phipps. 2001. Effect of oil supplementation of a diet containing a high concentration of starch on levels of trans fatty acids and conjugated linoleic acids in bovine milk. Anim. Sci. 73:533-540.

Or-Rashid, M. M., J. K. G. Kramer, M. A. Wood, and B. W. McBride. 2008. Supplemental algal meal alters the ruminal trans-18:1 fatty acid and conjugated linoleic acid composition in cattle. J. Anim. Sci. 86:187-196.
Palmquist, D. L., A. Lock, K. Shingfield, and D. Bauman. 2005. Biosynthesis of conjugated linoleic acid in ruminants and humans. Pages 179-217 in Advances in Food and Nutrition Research. Vol. 50. S. L. Taylor, ed. Elsevier Academic Press, San Diego, CA.

Papadopoulos, G., C. Goulas, E. Apostolaki, and R. Abril. 2002. Effects of dietary supplements of algae, containing polyunsaturated fatty acids, on milk yield and the composition of milk products in dairy ewes. J. Dairy Res. 69:357-365.

Pariza, M. W., Y. Park, and M. E. Cook. 2001. The biologically active isomers of conjugated linoleic acid. Prog. Lipid Res. 40:283-298.

Perfield, J. W., A. L. Lock, J. M. Griinari, A. Sæbø, P. Delmonte, D. A. Dwyer, and D. E. Bauman. 2007. Trans-9, cis-11 conjugated linoleic acid reduces milk fat synthesis in lactating dairy cows. J. Dairy Sci. 90:2211-2218.

Pulina, G., A. Nudda, G. Battacone, and A. Cannas. 2006. Effects of nutrition on the contents of fat, protein, somatic cells, aromatic compounds, and undesirable substances in sheep milk. Anim. Feed Sci. Technol. 131:255-291.

Recio, I., M. A. de la Fuente, M. Juárez, and M. Ramos. 2009. Bioactive components in sheep milk. Pages 83-104 in Bioactive Components in Milk and Dairy Products. Y. W. Park, ed. WileyBlackwell, Ames, IA.

Reynolds, C. K., V. L. Cannon, and S. C. Loerch. 2006. Effects of forage source and supplementation with soybean and marine algal oil on milk fatty acid composition of ewes. Anim. Feed Sci. Technol. 131:333-357.

Roy, A., A. Ferlay, K. J. Shingfield, and Y. Chilliard. 2006. Examination of the persistency of milk fatty acid composition responses to plant oils in cows given different basal diets, with particular emphasis on trans-C-18:1 fatty acids and isomers of conjugated linoleic acid. Anim. Sci. 82:479-492.

Shingfield, K. J., Y. Chilliard, V. Toivonen, P. Kairenius, and D. I. Givens. 2008. Trans fatty acids and bioactive lipids in ruminant milk. Adv. Exp. Med. Biol. 606:3-65.

Shingfield, K. J., C. K. Reynolds, G. Hervás, J. M. Griinari, A. S. Grandison, and D. E. Beever. 2006. Examination of the persistency of milk fatty acid composition responses to fish oil and sunflower oil in the diet of dairy cows. J. Dairy Sci. 89:714-732.

Shingfield, K. J., A. Sæbø, P. C. Sæbø, V. Toivonen, and J. M. Griinari. 2009. Effect of abomasal infusions of a mixture of octadecenoic acids on milk fat synthesis in lactating cows. J. Dairy Sci. 92:4317-4329.

Simopoulos, A. P. 2008. The importance of the omega-6/omega-3 fatty acid ratio in cardiovascular disease and other chronic diseases Exp. Biol. Med. 233:674-688.

Sinclair, L. A., S. L. Cooper, S. Chikunya, R. G. Wilkinson, K. G. Hallett, M. Enser, and J. D. Wood. 2005. Biohydrogenation of n-3 polyunsaturated fatty acids in the rumen and their effects on microbial metabolism and plasma fatty acid concentrations in sheep. Anim. Sci. 81:239-248.

Timmen, H., and S. Patton. 1988. Milk fat globules: Fatty acid composition, size and in vivo regulation of fat liquidity. Lipids 23:685-689.

World Health Organization. 2003. Diet, Nutrition and the Prevention of Chronic Diseases. Report of a Joint WHO/FAO Expert Consultation. WHO Technical Reports Series 916. World Health Organization, Geneva, Switzerland. 